\title{
ASPEK-ASPEK PENILAIAN KUALITAS GURU PAI
}

\author{
Adri Efferi \\ STAIN Kudus, Jawa Tengah, Indonesia \\ adri.efferi@gmail.com
}

\begin{abstract}
Abstrak
Guru sebagai pendidik adalah seseorang yang memberikan kontribusi kepada masyarakat dan bangsa. Budaya tinggi dan rendah, kemajuan atau kemunduran suatu masyarakat dan tingkat budaya negara sangat tergantung pada pendidikan dan pengajaran yang diberikan oleh guru. Penelitian ini mengkaji bagaimana cara memperbaiki kualitas mengajar guru Pendidikan Agama Islam (PAI) dengan menggunakan metode library reasearch. Berdasarkan analisis data, diperoleh hasil bahwa cara yang efektif dari pemerintah untuk memperbaiki kualitas mengajar guru Pendidikan Agama Islam (PAI) adalah dengan memberikan mereka apresiasi atau penghargaan berupa sertifikasi guru. Sertifikasi ini merupakan bukti formal pengakuan formalitas guru yang diberikan kepada guru sebagai tenaga profesional. Untuk itu, gurupun diharapkan mampu meningkatkan kompetensi dan profesionalitasnya.
\end{abstract}

\section{Kata kunci: kualitas, guru, PAI}

\begin{abstract}
Teacher as educator is someone who gives contribution to the society in a country. The culture level and the progress of society lie on the education quality. It can not be separated from teachers' role. The aim of this study was discussing and finding the way how to improve the Islamic Education teachers' quality. The method used in this study was library research. Based on the data analysis, the result showed that
\end{abstract}


the effective way from government to improve the Islamic Education teachers' quality is giving the appreciation. That appreciation is in the form of teachers' certification. It can be the formal proof that the government acknowledge them as professional personnel. Hopefully, the teachers are able to improve their competence and professionality.

Keywords: quality, teacher, Education, Islam, Studi

\section{A. Pendahuluan}

Sebagaimana yang telah seringkali diungkap, bahwa pendidikan merupakan aspek terpenting untuk dimiliki oleh setiap umat manusia. Karena dengan pendidikan dapat menciptakan perubahan sikap yang baik pada diri seseorang. Pendidikan pada umumnya mempunyai dua pilar utama yaitu pengajar dan yang diajar. Pengajar dalam konteks pendidikan formal, biasanya dikenal dengan panggilan seorang guru. Guru dalam proses belajar mengajar mempunyai tiga peranan yaitu sebagai pengajar, pembimbing dan administrator kelas. Sementara itu, terkait dengan yang diajar dalam kehidupan sehari-hari sering dipanggil murid atau siswa.

Sebagai sosok pengajar, guru sangat berperan dalam merencanakan dan melaksanakan pembelajaran. Oleh sebab itu guru dituntut untuk menguasai seperangkat pengetahuan (knowledges) dan keterampilan (skill) mengajar. Guru sebagai pembimbing diharapkan dapat memberikan bantuan kepada siswa dalam memecahkan masalah yang dihadapi. Peranan ini termasuk ke dalam aspek pendidik sebab tidak hanya menyampaikan ilmu pengetahuan, melainkan juga mendidik untuk mengalihkan nilai-nilai kehidupan. Hal tersebut menjelaskan bahwa tujuan pendidikan adalah mengubah tingkah laku peserta menjadi lebih baik. Guru sebagai administrator kelas berperan dalam pengelolaan proses belajar mengajar di kelas.

Oleh karena itu, guru merupakan komponen penting dalam upaya peningkatan mutu pendidikan nasional. Guru yang berkualitas, profesional dan berpengetahuan, tidak hanya berprofesi sebagai pengajar, namun juga pendidik, pembimbing, pengarah, pelatih, penilai dan pengevaluasi peserta didik. Berdasarkan Standar Nasional Kependidikan, guru harus memiliki empat kompetensi dasar yaitu kompetensi pedagogis, kompetensi sosial, kompetensi kepribadian, dan kompetensi profesional. Namun, kompetensi-kompetensi yang 
dimiliki guru saat ini masih terbatas, sehingga diperlukan suatu upaya untuk mengoptimalkan kompetensi-kompetensi tersebut. Guru yang bermutu dan profesional menjadi tuntutan masyarakat, seiring dengan tuntutan dunia kerja yang semakin ketat serta untuk mengikuti kemajuan era globalisasi. Untuk membentuk guru yang profesional sangat tergantung pada banyak hal yaitu guru itu sendiri, pemerintah, masyarakat dan orang tua.

Berdasarkan kenyataan yang ada, pemerintah telah mengupayakan berbagai hal, diantaranya sertifikasi guru. Dengan adanya program sertifikasi tersebut, kualitas mengajar guru akan lebih baik. Tulisan ini akan membahas beberapa hal terkait dengan guru, meskipun tidak secara spesifik membahas tentang guru PAI. Bagi penulis guru PAI, pada dasarnya sama saja dengan guru-guru yang lain seperti guru matematika, guru IPA dan lain sebagainya, meskipun dalam beberapa hal tentunya ada bebera kekhususan yang harus dimiliki oleh masing-masing jenis guru itu. Selanjutnya akan dibahas peran sentral guru, kompetensi guru, usaha peningkatan profesionalisme guru, usaha peningkatan kualitas guru dan kompetensi profesionalisme guru PAI.

\section{B. Pembahasan}

\section{Guru}

Guru sebagai pendidik adalah seorang yang berjasa besar terhadap masyarakat dan bangsa. Tinggi rendahnya kebudayaan masyarakat, maju atau mundurnya tingkat kebudayaan suatu masyarakat dan negara sebagian besar bergantung pada pendidikan dan pengajaran yang diberikan oleh guru-guru. Makin tinggi pendidikan guru, makin baik pula mutu pendidikan dan pengajaran yang diterima anak, dan makin tinggi pula derajat masyarakat. Oleh sebab itu para guru harus berkeyakinan dan bangga, bahwa mereka dapat menjalankan tugas itu. Satu hal lagi yang tidak kalah pentingnya adalah mereka harus berusaha menjalankan segenap tugas dengan sebaik-baiknya, sehingga masyarakat pada akhirnya akan sadar bahwa sesungguhnya betapa berat dan mulianya pekerjaan menjadi seorang guru itu. 
Pekerjaan sebagai guru adalah pekerjaan yang mulia, baik ditinjau dari sudut masyarakat dan negara maupun ditinjau dari sudut keagamaan. Tugas seorang guru tidak hanya mendidik. Maka, untuk melaksanakan tugas sebagai guru tidak sembarang orang dapat menjalankannya. Sebagai guru yang professional harus memenuhi berbagai syarat, yang ada dalam Undang-Undang No. 14 Tahun 2005 tentang Guru dan Dosen. Syarat-syarat tersebut dapat kita cermati dari beberapa pasal yang ada dalam UU tersebut, diantaranya sebagai berikut.

Pasal delapan menyebutkan bahwa guru wajib memiliki kualifikasi akademik, kompetensi, sertifikat pendidik, sehat jasmani dan rohani, serta memiliki kemampuan untuk mewujudkan tujuan pendidikan nasional. Kualifikasi akademik sebagaimana dimaksud dalam pasal 8 diperoleh melalui pendidikan tinggi program sarjana atau program diploma empat.

Kompetensi guru sebagaimana dimaksud dalam Pasal delapan meliputi kompetensi pedagogik, kompetensi kepribadian, kompetensi sosial, dan kompetensi profesional yang diperoleh melalui pendidikan profesi. Ketentuan lebih lanjut mengenai kompetensi guru sebagaimana dimaksud pada ayat (1) diatur dengan Peraturan Pemerintah (Pasal 10). Sertifikat pendidik sebagaimana dimaksud dalam Pasal delapan diberikan kepada guru yang telah memenuhi persyaratan. Sertifikasi pendidik diselenggarakan oleh perguruan tinggi yang memiliki program pengadaan tenaga kependidikan yang terakreditasi dan ditetapkan oleh Pemerintah. Sertifikasi pendidik dilaksanakan secara objektif, transparan, dan akuntabel. Ketentuan lebih lanjut mengenai sertifikasi pendidik diatur dengan Peraturan Pemerintah.

Disamping syarat-syarat seperti yang telah tercantum dalam UU di atas, tentunya masih ada syarat-syarat lain yang harus dimiliki guru jika kita menghendaki agar tugas atau pekerjaan guru mendatangkan hasil yang lebih baik. Salah satu syarat diatas adalah guru harus berkelakuan baik, maka didalamnya terkandung segala sikap, watak dan sifat-sifat yang baik. Beberapa sikap dan sifat yang sangat penting bagi guru diantaranya guru harus adil dalam memperlakukan anak-anak didik, misalnya dalam hal memberi nilai dan menghukum anak. 
Seorang guru harus percaya terhadap anak didiknya. Ini berarti bahwa guru harus mengakui bahwa anak-anak adalah makhluk yang mempunyai kemauan, mempunyai kata hati sebagai daya jiwa untuk menyesali perbuatannya yang buruk dan menimbulkan kemauan untuk mencegah hal yang buruk. Kesabaran juga merupakan syarat yang sangat diperlukan apalagi pekerjaan guru sebagai pendidik. Sifat sabar perlu dimiliki guru baik dalam melakukan tugas mendidik maupun dalam menanti jerih payahnya.

Seorang guru juga harus memiliki gezag atau kewibawaan. Tanpa adanya gezag pada pendidik tidak mungkin pendidikan itu masuk ke dalam sanubari anak-anak. Tanpa kewibawaan, muridmurid hanya akan menuruti kehendak dan perintah gurunya karena takut atau paksaan; jadi bukan karena keinsyafan atau karena kesadaran dalam dirinya. Seorang guru hendaklah memiliki sifat tertawa dan suka memberi kesempatan tertawa bagi murid-muridnya. Sifat ini banyak gunanya bagi seorang guru, antara lain akan tetap memikat perhatian anak-anak pada waktu mengajar, anak-anak tidak lekas bosan atau lelah. Sifat humor yang pada tempatnya merupakan pertolongan untuk memberi gambaran yang betul dari beberapa pelajaran. Yang penting lagi adalah humor dapat mendekatkan guru dengan muridnya, seolah-olah tidak ada perbedaan umur, kekuasaan dan perseorangan. Dilihat dari sudut psikologi, setiap orang atau manusia mempunyai 2 naluri (insting): (1) naluri untuk berkelompok, (2) naluri suka bermain-main bersama. Kedua naluri itu dapat kita gunakan secara bijaksana dalam tiap-tiap mata pelajaran, hasilnya akan baik dan berlipat ganda.

Guru menjalin hubungan yang baik dengan murid, juga sepatutnya bersikap baik terhadap guru-guru lain. Suasana baik diantara guru-guru nyata dari pergaulan ramah-tamah mereka di dalam dan di luar sekolah, mereka saling menolong dan kunjung mengunjungi dalam keadaan suka dan duka. Mereka merupakan keluarga besar, keluarga sekolah. Terhadap anak-anak, guru harus menjaga nama baik dan kehormatan teman sejawatnya. Bertindaklah bijaksana jika ada anak-anak atau kelas yang mengajukan kekurangan atau keburukan seorang guru kepada guru lain. 
Tugas dan kewajiban guru tidak hanya terbatas pada sekolah saja tetapi juga dalam masyarakat. Sekolah hendaknya menjadi cermin bagi masyarakat sekitarnya, dirasai oleh masyarakat bahwa sekolah itu adalah kepunyaannya dan memenuhi kebutuhan mereka. Sekolah akan asing bagi rakyat jika guru-gurunya memencilkan diri seperti siput dalam rumahnya, tidak suka bergaul atau mengunjungi orang tua murid-murid, memasuki perkumpulan-perkumpulan atau turut membantu kegiatan masyarakat yang penting dalam lingkungannya.

Guru harus selalu menambah pengetahuannya untuk meningkatkan kualitasnya dalam mengajar. Mengajar tidak dapat dipisahkan dari belajar. Guru yang pekerjaannya memberi pengetahuan-pengetahuan dan kecakapan-kecakapan kepada muridnya tidak mungkin akan berhasil baik jika guru itu sendiri tidak selalu berusaha menambah pengetahuannya. Jadi sambil mengajar sebenarnya guru itu belajar. Selain mempunyai pengetahuan yang dalam tentang mata pelajaran yang sudah menjadi tugasnya akan lebih baik lagi jika guru itu mengetahui pula tentang segala tugas yang penting-penting, yang ada hubungannya dengan tugasnya di dalam masyarakat. Guru merupakan tempat bertanya tentang segala sesuatu bagi masyarakat. Guru itu mempunyai dua fungsi istimewa yang membedakannya dari pegawai-pegawai dan pekerja-pekerja lainnya di dalam masyarakat. Fungsi yang pertama adalah mengadakan jembatan antara sekolah dan dunia ini. Fungsi yang kedua yaitu mengadakan hubungan antara masa muda dan masa dewasa.

\section{Kompetensi Guru}

Secara umum kompetensi dapat diartikan kemampuan secara umum yang harus dikuasai lulusan. Para ahli ada juga yang mengatakan menyatakan kompetensi adalah pernyataan yang menggambarkan penampilan suatu kemampuan secara bulat yang merupakan perpaduan antara pengetahuan dari kemampuan yang dapat diamati dan diukur. Salah satu ciri sebagai profesi, guru harus memiliki kompetensi sebagaimana dituntut oleh disiplin ilmu pendidikan (paedagogi) yang harus dikuasainya. Dalam hal kompetensi ini, Direktorat Tenaga Kependidikan telah memberi defi nisi kompetensi sebagai pengetahuan, keterampilan dan Nilainilai yang direfl eksikan dalam kebiasaan berfi kir dan bertindak. 
Berdasarkan Undang-undang No. 14 Tahun 2005 tentang Guru dan Dosen, pada bab IV kualifikasi dan kompetensi, pasal 7 ayat 2 berbunyi: Kompetensi guru sebagai agen pembelajaran meliputi kompetensi pedagogik, kompetensi kepribadian, kompetensi sosial dan kompetensi profesional.

Dalam Penjelasan Peraturan Pemerintah No 19 Tahun 2005 tentang Standar Nasional Pendidikan, Pemerintah telah merumuskan empat jenis kompetensi guru yaitu: (a) kompetensi pedagogik (kemampuan dalam pengelolaan peserta didik) yang meliputi: pemahaman wawasan atau landasan kependidikan, pemahaman terhadap peserta didik, pengembangan kurikulum/ silabus, perancangan pembelajaran, pelaksanaan pembelajaran yang mendidik dan dialogis, evaluasi hasil belajar, dan pengembangan peserta didik untuk mengaktualisasikan berbagai potensi yang dimilikinya; (b) kompetensi kepribadian (kemampuan kepribadian) yang harus: mantap, stabil, dewasa, arif dan bijaksana, berwibawa, berakhlak mulia, menjadi teladan bagi peserta didik dan masyarakat, mengevaluasi kinerja sendiri, dan mengembangkan diri secara berkelanjutan; (c) kompetensi sosial (kemampuan pendidik sebagai bagian dari masyarakat) untuk: berkomunikasi lisan dan tulisan, menggunakan teknologi komunikasi dan informasi secara fungsional, bergaul secara efektif dengan peserta didik, sesama pendidik, tenaga kependidikan, orangtua/wali peserta didik, dan bergaul secara santun dengan masyarakat sekitar; (d) kompetensi profesional (kemampuan penguasaan materi pembelajaran secara luas dan mendalam) yang meliputi: konsep, struktur, dan metoda keilmuan/teknologi/seni yang menaungi/koheren dengan materi ajar, materi ajar yang ada dalam kurikulum sekolah, hubungan konsep antar mata pelajaran terkait, penerapan konsep-konsep keilmuan dalam kehidupan seharihari, dan kompetisi secara profesional dalam konteks global dengan tetap melestarikan nilai dan budaya nasional.

Guru yang profesional adalah guru yang melakukan proses belajar sebagai sumber penghasilan kehidupan yang memerlukan keahlian, kemahiran, atau kecakapan yang memenuhi standar mutu. Prinsip-prinsip profesional yang harus dimiliki seorang guru adalah sebagai berikut:

1. Memiliki bakat, minat, panggilan jiwa dan idealisme. 
2. Memiliki kualifikasi pendidikan dan latar belakang pendidikan sesuai dengan bidang tugasnya.

3. Memiliki kompetensi yang diperlukan sesuai dengan bidang tugasnya.

4. Mematuhi kode etik profesi.

5. Memiliki hak dan kewajiban dalam melaksanakan tugas.

6. Memperoleh penghasilan yang ditentukan sesuai dengan prestasi kerjanya.

7. Memiliki kesempatan untuk mengembangkan profesinya secara berkelanjutan.

8. Memperoleh perlindungan hukum dalam melaksanakan tugas profesionalnya.

9. Memiliki organisasi profesi yang berbadan hukum.

Pada prinsipnya profesionalisme guru adalah guru yang dapat menjalankan tugasnya secara profesional, yang memiliki ciriciri antara lain: ahli di bidang teori dan praktek keguruan. Guru profesional adalah guru yang menguasai ilmu pengetahuan yang diajarkan dan ahli mengajarnya (menyampaikannya). Dengan kata lain guru profesional adalah guru yang mampu membelajarkan peserta didiknya tentang pengetahuan yang dikuasainya dengan baik. Senang memasuki organisasi Profesi Keguruan. Suatu pekerjaan dikatakan sebagai jabatan profesi salah satu syaratnya adalah pekerjaan itu memiliki organisasi profesi dan anggotaanggotanya senang memasuki organisasi profesi tersebut. Guru sebagai jabatan profesional seharusnya guru memiliki organisasi ini.

Fungsi organisasi profesi selain untuk melindungi kepentingan anggotanya juga sebagai dinamisator dan motivator anggota untuk mencapai karir yang lebih baik. Konsekuensinya organisasi profesi turut mengontrol kinerja anggota, bagaimana para anggota dalam memberikan pelayanan pada masyarakat. PGRI sebagai salah satu organisasi guru di Indonesia memiliki fungsi: (a) menyatukan seluruh kekuatan dalam satu wadah, (b) mengusahakan adanya satu kesatuan langkah dan tindakan, (c) melindungi kepentingan anggotanya, (d) menyiapkan program-program peningkatan kemampuan para anggotanya, (e) menyiapkan fasilitas penerbitan dan bacaan dalam rangka peningkatan kemampuan profesional, dan (f) mengambil 
tindakan terhadap anggota yang melakukan pelanggaran baik administratif maupun psikologis.

Memiliki latar belakang pendidikan keguruan yang memadai, keahlian guru dalam melaksanakan tugas-tugas kependidikan diperoleh setelah menempuh pendidikan keguruan tertentu, dan kemampuan tersebut tidak dimiliki oleh warga masyarakat pada umumnya yang tidak pernah mengikuti pendidikan keguruan. Ada beberapa peran yang dapat dilakukan guru sebagai tenaga pendidik, antara lain: (a) sebagai pekerja profesional dengan fungsi mengajar, membimbing dan melatih, (b) pekerja kemanusiaan dengan fungsi dapat merealisasikan seluruh kemampuan kemanusiaan yang dimiliki, (c) sebagai petugas kemashalakatkatan dengan fungsi mengajar dan mendidik masyarakat untuk menjadi warga negara yang baik.

Peran guru ini seperti menuntut pribadi harus memiliki kemampuan managerial dan teknis serta prosedur kerja sebagai ahli serta keikhlasan bekerja yang dilandaskan pada panggilan hati untuk melayani orang lain. Melaksanakan Kode Etik Guru, sebagai jabatan profesional guru dituntut untuk memiliki kode etik, seperti yang dinyatakan dalam Konvensi Nasional Pendidikan I Tahun 1988, bahwa profesi adalah pekerjaan yang mempunyai kode etik yaitu norma-norma tertentu sebagai pegangan atau pedoman yang diakui serta dihargai oleh masyarakat. Kode etik bagi suatu organisasi sangat penting dan mendasar, sebab kode etik ini merupakan landasan moral dan pedoman tingkah laku yang dijunjung tinggi oleh setia anggotanya. Kode etik berfungsi untuk mendisiplinkan setiap anggotanya guna meningkatkan diri, dan meningkatkan layanan profesionalismenya demi kemaslahatan orang lain.

Memiliki otonomi dan rasa tanggung jawab. Otonomi dalam artian mengatur diri sendiri, berarti guru harus memiliki sikap mandiri dalam mengambil keputusan sendiri dan dapat mempertanggungjawabkan keputusan yang dipilihnya. Memiliki rasa pengabdian kepada masyarakat. Pendidikan memiliki peran sentral dalam membangun masyarakat untuk mencapai kemajuan. Guru sebagai tenaga pendidikan memiliki peran penting dalam mencerdaskan kehidupan masyarakat tersebut. Untuk itulah guru dituntut memiliki pengabdian yang tinggi kepada masyarakat 
khususnya dalam membelajarkan anak didik. Bekerja atas panggilan hati nurani. Dalam melaksanakan tugas pengabdian pada masyarakat hendaknya didasari atas dorongan atau panggilan hati nurani. Sehingga guru akan merasa senang dalam melaksanakan tugas berat mencerdaskan anak didik. (Haryono, 2005: 2)

Untuk melihat apakah seorang guru dikatakan profesional atau tidak, dapat dilihat dari dua perspektif. Pertama, dilihat dari tingkat pendidikan minimal dari latar belakang pendidikan untuk jenjang sekolah tempat dia menjadi guru. Kedua, penguasaan guru terhadap materi bahan ajar, mengelola proses pembelajaran, mengelola siswa, melakukan tugas-tugas bimbingan, dan lain-lain. Dilihat dari perspektif latar belakang pendidikan, kemampuan profesional guru SLTP dan SLTA di Indonesia masih sangat beragam, mulai dari yang tidak berkompeten sampai yang berkompeten. Semiawan (1991: 10) mengemukakan hierarkhi profesi tenaga kependidikan, yaitu: (1) Tenaga Profesional merupakan tenaga kependidikan yang berkualifikasi pendidikan sekurang-kurangnya S1 (atau yang setara), dan memiliki wewenang penuh dalam perencanaan, pelaksanaan, penilaian dan pengendalian pendidikan/pengajaran. Tenaga kependidikan yang termasuk dalam kategori ini juga berwenang untuk membina tenaga kependidikan yang lebih rendah jenjang profesionalnya, misalnya guru senior membina guru yang lebih yunior. (2) Tenaga Semiprofessional merupakan tenaga kependidikan yang berkualifikasi pendidikan tenaga kependidikan D3 (atau yang setara) yang telah berwenang mengajar secara mandiri, tetapi masih harus melakukan konsultasi dengan tenaga kependidikan yang lebih tinggi jenjang profesionalnya, baik dalam hal perencana, pelaksanaan, penilaian maupun pengendalian pengajaran. (3) Tenaga Paraprofessional merupakan tenaga kependidikan yang berkualifikasi pendidikan tenaga kependidikan D2 ke bawah, yang memerlukan pembinaan dalam perencanaan, pelaksanaan, penilaian dan pengendalian pendidikan atau pengajaran. Menghadapi tantangan demikian, maka diperlukan guru yang benar-benar profesional.

H.A.R. Tilaar (1995: 205) memberikan empat ciri utama agar seorang guru terkelompok ke dalam guru yang profesional. Keempat ciri tersebut adalah: a) memiliki kepribadian yang matang dan berkembang (mature and developing personalitiy); b) mempunyai 
keterampilan membangkitkan minat peserta didik; c) memiliki penguasaan ilmu pengetahuan dan teknologi yang kuat; dan d) sikap profesionalnya berkembang secara berkesinambungan.

Di sisi lain, ada empat prasyarat lain agar seorang guru dapat profesional. Masing-masing adalah kemampuan guru mengolah atau menyiasati kurikulum, kemampuan guru mengaitkan materi kurikulum dengan lingkungan, kemampuan guru memotivasi siswa untuk belajar sendiri, dan kemampuan guru untuk mengintegrasikan berbagai bidang studi atau mata pelajaran menjadi kesatuan konsep yang utuh. (Suyanto, 2001: 145 - 146)

\section{Usaha Peningkatan Profesionalisme Guru}

Ada beberapa usaha peningkatan profesionalisme guru. Pertama, dari sisi lingkungan tempat guru mengajar. Setiap guru mengikuti pelatihan atau penataran, diharapkan dari dirinya akan ada peningkatan dalam hal kemampuan dan kemauan. Penataran berfungsi memotivasi hasrat guru untuk menjadi yang terbaik. Serta mengembangkan wawasan keilmuannya dengan memberikan pembekalan materi. Kedua, pola pengelolaan pendidikan yang selama ini sangat sentralistik telah memposisikan para guru hanya sekedar operator pendidikan. Jadi guru cenderung mengajar hanya memindahkan pengetahuan saja. Pola pengelolaan pendidikan ini perlu diubah menjadi pola desentralistik. Pengembangan kemampuan berpikir logis, kritis, dan kreatif perlu dilaksanakan. Mutu pendidikan tidak hanya mengukur aspek knowledge tetapi juga skill, perilaku budi pekerti serta ketrampilan. Guru harus dapat mengembangkan daya kritis dan kreatif siswa. Kedua aspek internal guru sendiri. Perilaku guru diharapkan mempunyai perilaku yang baik. Perubahan perilaku ini dapat dilakukan melalui pelatihan dan penataran.

Untuk mengantisipasi tantangan dunia pendidikan yang semakin berat, maka profesionalisme guru harus dikembangkan. Beberapa cara yang dapat ditempuh dalam pengembangan profesionalitas guru menurut Balitbang Diknas antara lain adalah:

1. Perlunya revitalisasi pelatihan guru yang secara khusus dititikberatkan untuk memperbaiki kinerja guru dalam meningkatkan mutu pendidikan dan bukan untuk meningkatkan sertifikasi mengajar semata-mata; 
2. Perlunya mekanisme kontrol penyelenggaraan pelatihan guru untuk memaksimalkan pelaksanaannya;

3. Perlunya sistem penilaian yang sistemik dan periodik untuk mengetahui efektivitas dan dampak pelatihan guru terhadap mutu pendidikan;

4. Perlunya desentralisasi pelatihan guru pada tingkat kabupaten/kota sesuai dengan perubahan mekanisme kelembagaan otonomi daerah yang dituntut dalam UU No. 22/1999;

5. Perlunya upaya-upaya alternatif yang mampu meningkatkan kesempatan dan kemampuan para guru dalam penguasaan materi pelajaran;

6. Perlunya tolok ukur kemampuan profesional sebagai acuan pelaksanaan pembinaan dan peningkatan mutu guru;

7. Perlunya peta kemampuan profesional guru secara nasional yang tersedia di Depdiknas dan Kanwil-kanwil untuk tujuantujuan pembinaan dan peningkatan mutu guru;

8. Perlunya untuk mengkaji ulang aturan atau kebijakan yang ada melalui perumusan kembali aturan atau kebijakan yang lebih fl eksibel dan mampu mendorong guru untuk mengembangkan kreativitasnya;

9. Perlunya reorganisasi dan rekonseptualisasi kegiatan Pengawasan Pengelolaan Sekolah, sehingga kegiatan ini dapat menjadi sarana alternatif peningkatan mutu guru;

10. Perlunya upaya untuk meningkatkan kemampuan guru dalam penelitian, agar lebih bisa memahami dan menghayati permasalahan-permasalahan yang dihadapi dalam proses pembelajaran.

11. Perlu mendorong para guru untuk bersikap kritis dan selalu berusaha meningkatkan ilmu pengetahuan dan wawasan;

12. Memperketat persyaratan untuk menjadi calon guru pada Lembaga Pendidikan Tenaga Kependidikan (LPTK);

13. Menumbuhkan apresiasi karier guru dengan memberikan kesempatan yang lebih luas untuk meningkatkan karier;

14. Perlunya ketentuan sistem credit point yang lebih fleksibel untuk mendukung jenjang karier guru, yang lebih menekankan 
pada aktivitas dan kreativitas guru dalam melaksanakan proses pengajaran.

Untuk lebih mendorong tumbuhnya profesionalisme guru selain apa yang telah diutarakan oleh Balitbang Diknas, tentunya "penghargaan yang profesional" terhadap profesi guru masih sangat penting. Seperti yang diundangkan bahwa guru berhak mendapat tunjangan profesi. Realisasi pasal ini tentunya akan sangat penting dalam mendorong tumbuhnya semangat profesionalisme pada diri guru. Dengan adanya pengembangan profesionalisme guru, maka peranan guru harus lebih ditingkatkan. Guru tidak hanya disanjung, dihormati, disegani, dikagumi, diagungkan, tetapi guru harus lebih mengoptimalkan rasa tanggungjawabnya. Peranan guru sangat penting dalam mencerdaskan kehidupan bangsa. Ada pepatah Sunda mengatakan, guru adalah "digugu dan ditiru" (diikuti dan diteladani), berarti guru harus memiliki: penguasaan pengetahuan dan keterampilan, kemampuan profesional yang baik, idealisme dan pengabdian yang tinggi, memiliki keteladanan untuk diikuti dan dijadikan teladan.

Sebaliknya seorang guru yang berpenampilan premanisme, akan berpengaruh buruk terhadap sikap dan moral siswa. Upaya meningkatkan profesionalisme guru menurut Gerstner dkk., peranan guru tidak hanya sebagai teacher (pengajar), tapi guru harus berperan sebagai:

1. Pelatih (coach), guru yang profesional yang berperan ibarat pelatih olah raga. Ia lebih banyak membantu siswanya dalam permainan, bedanya permainan itu adalah belajar (game of learning) sebagai pelatih, guru mendorong siswanya untuk menguasai alat belajar, memotivasi siswa untuk bekerja keras dan mencapai prestasi setinggi-tingginya.

2. Konselor, guru akan menjadi sahabat siswa, teladan dalam pribadi yang mengundang rasa hormat dan keakraban dari siswa, menciptakan suasana dimana siswa belajar dalam kelompok kecil di bawah bimbingan guru.

3. Manajer belajar, guru akan bertindak ibarat manajer perusahaan, ia membimbing siswanya belajar, mengambil prakarsa, mengeluarkan ide terbaik yang dimilikinya. Di 
sisi lain, ia bertindak sebagai bagian dari siswa, ikut belajar bersama mereka sebagai pelajar, guru juga harus belajar dari teman seprofesi. Sosok guru itu diibaratkan segala bisa.

Wujud nyata pemerintah dalam peningkatan kualitas guru salah satunya dengan sertifikasi guru. Sertifikasi guru adalah proses pemberian sertifikat pendidik pada guru. Sertifikat guru adalah sebuah sertifikat yang ditandatangani oleh perguruan tinggi penyelenggara sertifikasi sebagai bukti bahwa bukti formal pengakuan formalitas guru yang diberikan kepada guru sebagai tenaga profesional. Sertifikat ini diberikan kepada guru yang telah memenuhi standar profesional. Guru profesional merupakan syarat mutlak untuk menciptakan sistem dan praktek yang berkualitas.

Tujuan utama dalam mengikuti sertifikasi bukan untuk mendapatkan tunjangan profesi melainkan untuk menunjukkan bahwa yang bersangkutan telah memiliki kompetensi sebagaimana disyaratkan dalam kompetensi guru. Dengan menyadari hal ini, maka guru tidak akan mencari cara lain guna memperoleh sertifikat profesi kecuali mempersiapkan diri dengan belajar yang benar untuk menghadapi sertifikasi. Berdasarkan hal tersebut, maka sertifikasi akan membawa dampak positif yaitu meningkatkan kualitas guru.

Adapun tujuan dari sertifikasi adalah menentukan kelayakan guru dalam melaksanakan tugas sebagai agen pembelajaran dan mewujudkan tujuan pendidikan nasional, meningkatkan proses dan mutu hasil pendidikan, meningkatkan martabat guru, dan meningkatkan profesionalitas guru. Sedangkan manfaat sertifikasi guru, dapat dirinci sebagai berikut: (a) melindungi profesi guru dari praktik-praktik yang tidak kompetensi yang dapat merusak citra guru, melindungi masyarakat dari praktik-praktik pendidikan yang tidak berkualitas dan tidak profesional, dan meningkatkan kesejahteraan guru.

Setelah melalui sertifikasi, guru akan menjadi tenaga yang profesional. Dalam melaksanakan tugas sebagai tenaga profesional, guru berkewajiban untuk: (a) merencanakan pembelajaran, melaksanakan proses pembelajaran yang bermutu, serta menilai dan mengevaluasi hasil penilaian; (b) meningkatkan dan mengembangkan kualifikasi akademik dan kompeten serta berkelanjutan sejalan 
dengan perkembangan ilmu pengetahuan, teknologi, dan seni; (c) bertindak objektif dan tidak diskriminatif atas dasar pertimbangan jenis kelamin, agama, suku, ras dan kondisi fisik atau latar belakang keluarga dan status sosial ekonomi peserta didik dalam belajar; (d) menjunjung tinggi peraturan perundang-undangan, hukum, kode etik guru serta nilai-nilai agama dan etika; dan memelihara serta memupuk kesatuan dan persatuan bangsa.

\section{Kompetensi Profesionalisme Guru Agama Islam}

Sebagaimana layaknya makna profesional bagi guru umum, maka guru agama pun mestilah seorang profesional. Seperti kesimpulan di atas bahwa guru profesional adalah guru yang memiliki kemampuan khusus dalam bidang pendidikan. Kemampuan atau kompotensi mempunyai kaitan yang erat dengan intraksi belajar mengajar dalam proses pembelajaran. Dimana seseorang guru akan ragu-ragu menyampaikan meteri pelajaran apabila tidak diimbangi dengan kompetensi seperti penguasaan bahan, begitu juga dengan pemilihan dan penggunaan metode yang tidak sesuai dengan materi akan menimbulkan kebosanan dan mempersulit pemahaman belajar siswa. Dengan demikian profesionalitas seseorang guru sangat mendukung dalam rangka merangsang motivasi belajar siswa dan sekaligus tercapainya intraksi belajar mengajar sebagai mestinya.

Proses intraksi belajar mengajar merupakan suatu proses yang mengandung serangkaian perbuatan guru dan siswa atas timbal balik yang langsung dalam situasi pendidikan untuk mencapai tujuan tertentu. Intraksi guru dengan siswa bukan hanya dalam penguasaan bahan ajar, tetapi juga dalam penerimaan nilai-nilai, pengembangan sikap serta mengatasi kesulitaan-kesulitan yang dihadapi oleh siswa. Dengan demikian dalam interaksi belajar mengajar dalam rangka menimbulkan motivasi belajar siswa, guru bukan hanya saja sebagai pelatih dan pengajar tetapi juaga sebagai pendidik dan pembimbing (Ibrahim dan Sukmadinata, 1996: 33-34)

Kemampuan atau profesionalitas guru (termasuk guru agama) menurut Usman (2002: 18-19) meliputi hal-hal berikut ini:

1. Menguasai landasan kependidikan, yang meliputi: a) Mengenal tujuan pendidikan nasional untuk mencapai tujuan, b) Mengenal fungsi sekolah dalam masyarakat, dan 
c) Mengenal prinsip-prinsip psikologi pendidikan yang dapat dimanfaatkan dalam proses belajar mengajar.

2. Menguasai bahan pengajaran, yang meliputi: a) Menguasai bahan pengajaran kurikulum pendidikan pendidikan dasar dan menengah dan b) Mengusai bahan pengayaan.

3. Menyusun program pengajaran, yang meliputi: a) Menetapkan tujuan pembelajaran, b) Memiliki dan mengembangkan bahan pembelajaran, c) Memiliki dan mengembangkan media pengajaran yang sesuai, dan d) Memilih dan memanfaatkan sumber belajar

4. Melaksanakan program pengajaran, yang meliputi: a) Menciptakan iklim belajar mengajar yang tepat, b) Mengatur ruangan belajar, dan c) Mengelola intraksi belajar mengajar

5. Menilai hasil belajar mengajar yang telah dilaksanakan, yang meliputi: a) Menilai prestasi murid untuk kepentingan pengajaran, dan b) Menilai proses belajar mengajar yang telah dilaksanakan.

Sesuai dengan kutipan di atas, maka seorang guru profesional adalah guru yang mempunyai strategi mengajar, menguasai bahan, mampu menyusun program maupun membuat penilaian hasil belajar yang tepat. Selain hal di atas guru juga mesti memiliki kemampuan dalam membangkitkan motivasi bagi belajar siswa. Mengenai hal ini menurut Ibrahim dan Syaodih (1996: 28) ada beberapa kemampuan yang mesti dimiliki oleh guru yaitu: Pertama, menggunakan cara atau metode dan media mengajar yang bervariasi. Dengan metode dan media yang bervariasi kebosanan pun dapat dikurangi atau dihilangkan. Kedua, memilih bahan yang menarik minat dan dibutuhkan siswa. Sesuatu yang dibutuhkan akan menarik perhatian, dengan demikian akan membangkitkan motivasi untuk mempelajarinya. Ketiga, Memberikan sarana antara lain ujian semester, ujian tegah semester, ulangan harian dan juga kuis. Keempat, memberikan kesempatan untuk sukses. Bahan atau soal yang sulit yang hanya bisa dicapai siswa yang pandai. Agar siswa yang kurang pandai juga bisa maka diberikan soal yang sesuai dengan kepandainnya. Kelima, diciptakan suasana belajar yang menyenangkan. Dalam hal ini di lakukan guru dengan cara belajar yang punya rasa persahabatan, punya humor, pengakuan keberadaan 
siswa dan menghindari celaan dan makian. Keenam, Mengadakan persaingan sehat melalui hasil belajar siswa. Dalam persaingan ini dapat diberikan pujian, ganjaran ataupun hadiah.

Sejalan dengan kutipan di atas, maka profesionalitas guru adalah rangka motivasi siswa untuk sukses dalam belajar akan terlihat dengan kemampuan di dalam interaksi belajar mengajar yang muncul indikator penggunaan metode dan media yang bervariasi, pemilihan bahan yang menarik minat, pemberian kesempatan untuk sukses, penyajian suasana belajar mengajar yang menyenangkan dan juga pengadaan persaingan sehat. Beberapa pendapat menjelaskan tentang kompotensi guru agama dalam rangka motivasi siswa antara yaitu:

\section{f. Penggunaan metode dan media yang bervariasi.}

Di dalam intraksi belajar mengajar tidaklah kita temui selamanya berjalan dengan sukses, pasti ada hal-halyang menyebabkan siswa merasa bosan mengikuti pelajaran sehingga materi yang disampaikan oleh guru tidak dapat dipahami dan dikuasainya secara obtimal. Salah satu yang menyebabkan timbulnya kebosanan siswa dalam belajar adalah penggunaan metode dan media yang menoton. Jadi jika terdapat di antara siswa menentang pelajaran yang diberikan maka salah satu sebabnya adalah masalah metode dan media yang di pergunakan guru tidak sesuai dengan materi yang disampaikan. Misalnya seorang guru hanya menggunakan satu macam metode dan media dalam berbagai materi pelajaran, siswapun akan merasa bosan dan tidak mengikuti pelajaran sebaimana yang diiginkan. Oleh sebab itu suksesnya intraksi belajar mengajar harus dibarengi dengan metode dan media yang bervariasi agar menghasilkan pembelajaran sebagaimana harusnya. Dengan demikian penggunaan metode dan media yang bervariasi adalah salah satu pendorong bagi siswa (Hamalik, 2002: 16). Dari kutipan tersebut, dapat dipahami bahwa variasi metode dan media dalam interaksi belajar mengajar adalah hal yang penting dalam rangka membangkitkan motivasi belajar siswa mengikuti pelajaran.

\section{g. Memilih bahan yang menarik minat belajar siswa}

Kondisi belajar mengajar yang efektif adalah adanya minat dan perhatian siswa dalam belajar. Minat merupakan suatu sifat yang relatif menetap pada diri seseorang. Minat besar sekali pengaruhnya 
terhadap belajar sebab dengan minat seseorang akan melakukan suatu yang diminatinya. Sebaliknya tampa minat seseorang tidak mungkin melakukan sesuatu.(Usman, 2002: 27)

Sejalan dengan kutipan di atas sepatutnya seorang guru berusaha untuk menarik minat belajar siswa, walaupun pada kenyataannya tidak semua materi yang di sampaikan oleh guru disukai siswa. Tetapi disinilah tugas guru memahami sifat, mental, minat dan kebutuhan siswa agar dia bisa memberikan bimbingan dan pelajaran dengan sebaik-baiknya untuk menarik minat siswa. Beberapa cara membangkitkan minat belajar siswa, yaitu: a) Mengajar dengan cara menarik, b) Mengadakan selingan yang sehat, c) Menggunakan alat peraga, d) Sedapat mungkin mengurangi/menghilangkan sesuatu yang menyebabkan perhatian yang tak perlu, e) Dapat menunjukkan kegunaan bahan pelajaran yang di berikan, dan f) Berusaha mengadakan hubungan antara apa yang sudah ada diketahui murid dengan yang akan diketahuinya (Tim Dikdatik, 1993: 23)

\section{h. Memberikan sasaran antara, seperti ujian semester, ujian tegah semester, ulangan harian dan kuis.}

Pengetahuan yang tidak diulang-ulang atau tidak adanya pengujian akan mudah hilang dan tidak akan menetap dalam ingatan. Tetapi pengetahuan yang sering di ulang-ulang akan menjadi pengetahuan dan dapat digunakan. Maka pada waktu intraksi belajar mengajar guru hendaknya sering mengadakan ulangan yang teratur, agar bahan pelajaran yang di ajarkan itu benar-benar dimiliki murid dan siap digunakan. Ulangan harian atau kuis diadakan apabila: a) Sebagian besar murid-murid tidak mengerjakan tugas yang diberikan, b) Pelajaran yang lampau telah dilupakan, dan c) Jika mungkin sebelum pelajaran dimulai. Sedangkan ulangan tengah semester dan semester diadakan pada waktu sebelum libur (Tim Dikdatik, 1993: 26) langan harian dan kuis diadakan oleh guru saat berlangsungnya proses belajar mengajar dengan tujuan sebagai berikut : a) Untuk mengetahui keberhasilan dan kegagalan proses belajar mengajar, dan b) Untuk mengetahui keadaan yang sebenarnya dan proses belajar mengajar dengan baik (Thoha, 1996: 47).

Oleh sebab itu, tujuan ulangan harian atau kuis untuk perbaikan proses belajar mengajar, maka sebagian guru hendaknya 
memiliki kebesaran hati mencari kekurangannya dalam proses belajar mengajar seperti metodologi, didaktik, motivasi dan penguasaan terhadap bahan yangt diajarkan. Dengan demikian termasuk juga tujuan ulangan harian atau kuis untuk merangsang siswa agar lebih rajin belajar dan sekaligus mengetahui bagianbagian materi yang belum dikuasainya. Sedangkan ujian semester untuk mengukur keberhasilan belajar siswa ataupun kelulusan naik kelas atau tidak (Thoha, 1996: 48)

\section{i. Pemberian kesempatan untuk sukses}

Pemberian kesempatan untuk sukses adalah pemberian soal kepada siswa sesuai dengan kemampuannya. Sebagai guru hendaknya memahami bahwa murid/siswa tidaklah semua punya kesamaan tingkat pengetahuannya, dimana sebagian ada yang pintar, ada yang sedang dan ada pula yang bodoh. (Nasution, 2000: 33) Mengenai pemberian soal kepada siswa Thoha (1996: 145) mengatakan: Pemberian soal haruslah tidak terlalu sukar dan tidak terlalu mudah, karena bilamana soal memiliki tingkat kesukaran yang maksimal maka murid/siswa yang punya intelegensi di bawah dan sedang mungkin kesukaran dan tidak mampu menjawab secara optimal yang akhirnya tidak pernah merasa sukses dalam belajar, artinya tidak ada kesempatan untuk sukses.

Jadi dengan berpedoman kepada kutipan di atas dapat dipahami bahwa soal yang diberikan guru mestinya jangan terlalu mudah, karena tidak ada nantinya pembeda yang pandai, yang sedang dan yang bodoh. Dan jangan pula terlalu payah, karena nantinya siswa yang tidak pernah mendapatkan kesempatan untuk sukses, yang memungkinkan motivasi belajar tidak timbul. Akhirnya tidak mampu memahami pelajaran, dan malas untuk mengikuti intraksi belajar mengajar.

\section{j. Penyajian suasana belajar mengajar yang menyenangkan}

Siswa lebih senang melanjutkan belajarnya jika kondisi pengajaran menyenangkan. Jadi guru harus berusaha semaksimal mungkin didalam intraksi belajar mengajar dalam rangka memberikan motivasi bagi siswa agar mereka giat terus belajar dan mencapai tujuan. Cara untuk menyenangkan siswa dalam belajar adalah: a) Usahakan jangan mengulangi hal-hal yang mereka ketahui, 
sebab mereka jenuh, b) Suasana fisik kelas jangan membosankan, c) Hindarkan dari frustasi, seperti pertanyaan yang tak masuk akal, d) Hindarkan suasan kelas yang bersifat emosional sebagai akibat adanya kontak personal, e) Siapkan tugas-tugas yang menantang selama diselenggarakan intraksi belajar mengajar, f) Berikan siswa pengetahuan tentang hasil-hasil yang telah di capai masing-masing siswa, dan g) Berikan ganjaran yang pantas terhadap usaha-usaha yang dilakukan oleh siswa (Hamalik, 2002: 161).

\section{k. Mengadakan persaingan sehat}

Persaingan, sebenarnya adalah berdasarkan kepada dorongan untuk kedudukan dan penghargaan. Kebutuhan akan kedudukan dan penghargaan adalah merupakan kebutuhan yang sangat penting bagi pertumbuhan dan perkembangan. Oleh karena itu persaingan dapat menjadi tenaga pendorong yang sangat besar bagi perkembangan belajar siswa. Persaingan dalam rangka memotivasi belajar siswa dapat dilakukan guru dalam bentuk bermacam mata pelajaran. Dan biasanya persaingan secara sehat yang diadakan guru selalu diikuti dengan ganjaran seperti pemberian hadiah ataupun pujian, sesuai dengan bentuk dan tingkat persaingan sehat itu ada hal-hal yang perlu diperhatikan sebagaimana berikut ini: a) Persaingan jalan terlalu intensif, sebab akan mengakibatkan halhal negatif, seperti anak yang lemah akan merasa dirinya tidak mampu dan putus asa, b) Persaingan harus diadakan dalam suasana yang jujur, yang sportif, c) Semua anak ikut bersaing hendaknya mendapat penghargaan, baik yang menang maupun yang kalah, dan d) Hendaknya persaingan itu berjenis-jenis, agar yang menang tidak itu-itu saja (Daen, 1973: 167) Dengan demikian jika persaingan tersebut dilaksanakan dengan adanya aturan-aturan sebagauimana yang di atas, maka persaingan itu akan jadi persaingan sehat yang merupakan motivasi yang berperan untuk belajar siswa.

Dengan motivasi tersebut siswa-siswa berlomba memahami dan menyelesaikan hal-hal yang berkaitan dengan belajar sehingga mencapai secara optimal. Bila profesionalitas guru yang memiliki indikator seperti diatas direalisasikan dalam intraksi belajar mengajar maka siswa akan aktif mengikuti intraksi belajar mengajar, menyelesaikan tugas-tugas dengan penuh kesadaran, mudah 
memahami materi yang diajarkan oleh guru. Pada kondisi yang seperti itu maka kesuksesan belajar dapat tercapai secara maksimal.

\section{Simpulan}

Menjadi seorang guru pada zaman sekarang merupakan satu profesi yang sangat diminati. Disamping tugas mulia yang diembannya, profesi ini juga menjanjikan kehidupan yang layak, sama seperti profesi-profesi lain yang sudah ada dan memang terbukti menjanjikan kesejahteraan. Namun sayangnya, semakin banyak profesi ini diminati dan semakin besar tingkat penghargaan yang diterima, belum berbanding signifikan dengan kualitas atau mutu pengajaran yang diterima anak didik atau siswa. Oleh karena itu berbagai usaha harus dilakukan untuk menjaga kualitas pengajaran seorang guru tersebut, baik yang dilakukan oleh pemerintah, pihak sekolah maupoun pribadi guru yang bersangkutan.

Salah satu wujud nyata pemerintah dalam peningkatan kualitas guru adalah dengan sertifikasi guru. Sertifikasi guru adalah proses pemberian sertifikat pendidik pada guru. Sertifikat guru adalah sebuah sertifikat yang ditandatangani oleh perguruan tinggi penyelenggara sertifikasi sebagai bukti bahwa bukti formal pengakuan formalitas guru yang diberikan kepada guru sebagai tenaga profesional. Sertifikat ini diberikan kepada guru yang telah memenuhi standar profesional. Guru profesional merupakan syarat mutlak untuk menciptakan sistem dan praktek yang berkualitas.

Akhirnya, hendaklah seorang guru menyadari betapa penting dan muliannya aktivitas yang mereka laksanakan. Itu semua tidak bisa diukur dengan seberapa besar gaji dan tunjangan yang akan diterima. Oleh karena itu, untuk memperbaiki kualitas mengajar guru, disamping masukan dari para ahli, satu hal yang juga harus disadari, janganlah kegiatan mulia ini hanya dinilai dari seberapa besar kesejahteraan (finansial) yang akan diperoleh. Tetapi hendaknya ini juga dipandang sebagai investasi moral (pahala), dari ilmu yang telah diberikan yang balasannya sungguh sangat tidak terhingga. Dengan kesadaran ini, setiap pribadi guru akan senantiasa memperbaiki kualitas kerjanya dan berusaha menampilkan yang terbaik sebagi tuntutan dari profesinya. 
Adri Efferi

\section{DAFTAR PUSTAKA}

Daen, Amir. 1973. Pengantar Ilmu Pendidikan. Surabaya: Usaha Nasional.

Danim, Sudarman. 1994. Media Komunikasi Pendidikan. Jakarta: Bumi Aksara.

Departemen Pendidikan Nasional. 2001. Peningkatan Mutu Pendidikan di Sekolah Dasar. Jakarta: PEQIP.

Hamalik, Oemar. 2002. Perencanaan Pengajaran Berdasarkan Pendekatan Sistem. Jakarta: Bumi Aksara.

Harefa, Andrias. 1999. Membangkitkan Roh Profesionalisme. Jakarta: Gramedia.

Nasution, S. 2000. Berbagai Pendekatan dalam Proses Belajar dan Mengajar. Jakarta : Bumi Aksara.

Nurdin, Syafruddin. 2002. Guru Profesinal dan Implementasi Kurikulum. Jakarta : Ciputat Pers.

Ibrahim, R dan Nana Syaodih S. 1996. Perencanaan Pengajaran. Jakarta: Rineka Cipta.

Semiawan, Conry R. 1991. Mencari Strategi Pengembangan Pendidikan Nasional Menjelang Abad-21. Jakarta: PT. Gramedia.

Suyanto. 2001. Wajah dan Dinamika Pendidikan Anak Bangsa. Jakarta: Adicipta.

Thoha, M. Chabib. 1996. Tehnik Evaluasi Pendidikan. Jakarta: Raja Grafindo Persada.

Tilaar, H.A.R. 1999. Manajemen Pendidikan Nasional. Bandung: Remaja Rosdakarya.

Tim Didaktik Metodik Kurikulum IKIP Surabaya. 1993. Pengantar Didaktik Metodik Kurikulum PBM. Jakarta : Raja Grafindo Persada.

Usman, Muhammad Uzer. 2002. Menjadi Guru Profesional. Bandung: Remaja Rosda Karya. 